of I'atchetl versus Sterling Engineering Co., Ltd., cames before the House of Lords from the Court of A.ppoal, Mr. Patchett's application was rofuscd because undor the Common Law of the Land overy invention, according to tho circurnstances in which it was made, belongs wholly either to the employer or to the employee, in tho absence of an express agreement to the contrary. Since then the Section in question has virtually become a dead letter and the presont Bill was intendod to rectify this by giving in Clause 1, sub-section 1, both the employer and tho employee a right to so much, il any, of the benefit of an invention or patent as may be just. Sub-section 2 of Clause 1 then changes the law as laid down in the Putchett ease by stating in offect that tho Court or Comptrollor of Patents shall not be bound by any rule of law or implied agreoment undor which the benefit would belong exelusively to one of the parties. The power to apportion, how $\theta v e r$, does not prevent effect boing given to the express terms of any agreoment which may have boon reached by employer and employees as to who shall have the benefit, either in the terms of employment or "in circumstances connocted therewith", but it does not give power to appor tion the legal title. The second reading of the Bill was not opposed, though it was suggested that some guidance should be given to the Court or the Comptroller by indicating what factors should bo taken into account in determining what is just.

\section{Smuts as a Man of Science}

Is his Smuts Memorial Lecture at the University of Cambridge last Novomber, now published under the title Smuts: Study for a Portruit (Pp. 31. London: Cambridge University Press, 1965. 3s. 6d. net), Prof. W. K. Hancock re-examinos the presidential address, "The Sciontific World Picture of 'T'o-day", which Smuts delivered to the British Association for the Advancement of Science at its centenary meeting in 1931. Smuts him. self concluded that his world picture was necessarily provisional and that to-morrow would cortainly be difforent, but whilo some recent developments in astronomy have callod in question Smuts's confrontation of cosmic decline and organic evolution, all ton of the scientific colleaguos whom Prof. Hancock consulted agreed as to tho aceuracy and good proportions of Smuts's factual reporting-eight of them considorod that, with some reservations, the lecture would be just as much worth hoaring to-day as whon it was deliverod. Ono who hold a contrary opinion did not accopt its holistic concept; tho other adverse critic, an astronomer, appoared to start from the Baconian theory of scientific method. Prof. Hancock himself maintains that the lecture has a religious as woll as a scientific character and recognizes in it two languages of discourse-Smuts usks questions not only about the natural world but also about his own placo within it. Ho asks both what makes the universe behave as it docs and what makes him behave as he does, the latter leading him into the further questions how ought he to behave and what values did he recognize and maintain? It is from the answors Smuts attempted to give to these questions that Prof. Hancock attempts to portray Srruts as a man of scieneo and to outline his religious odyssoy. He suggests that the address to the British Association was both a summation of his book, Holism and Evolution, and a programmo for a new book. Later, Prof. Hancock hopes to produce the ovidenco that Smuts gavo a now deal to South Africen scientists and to science in South Africa. Here ho only depiets the progress of Smuts from his affirmalion in 1932 that the human spirit has firm anchorago, and merits responso and hospitality from a friendly and kindly univorse, to his belief that the moral govornment of the world is inseparablo from our moral backing, through the Second World War years, and his summit of 1943 to the chasm and disappointmont of his last decade.

\section{The Wellcome Trust}

THw fifth report of the Wollcomo Trust covors the years September 1962 August 1964, during which the Trustees allocated moro than $£ 2$ million in support of experimental and historical research in human and animal medicine, bringing the total allocation since the creation of the Trust to more than $£ 7$ million (Pp. 102. London: 'Thes Wolleome Trust, 1965). Fifty-eight buildings for rosearch were completed and another 28 are under construction. New eapital grants for buildings during the period totalled $£ 784,550$, including one of $£ 60,000$ to the Royal Society to cover the cost of meeting-rooms in its new premisos at Carlton House Terrace. Grants for equipment are now concentratod on spccial cases for which independent funds can be most useful, and grants for this purposo during the period totalled $£ 427,520$. Besides the grant to create a Wollcome research fellowship for Prof. L. C. Beadle at Makerere University College, Kampala, Uganda, to enable him to spend all his time on resoarch and writing up his results after rotiring from his teaching post, research fellowships, scholarships and personal grants amounted to $£ 336,175$, whilo $£ 148,932$ was allocated for resoarch expenses and $£ 75,652$ for travel grants. Grants for the costs of symposia amounted to $£ 5,100$, and grants in aid of publications to $£ 10,300$. Of the $£ 35,425$ for medical research, museums and libraries, $£ 20,700$ went to the Faculty of Radiologists, London, towards the establishment and maintenance for three years of a library of radiographs for use as a research reference and teaching collection. $£ 215,846$ were expended on the running exponses of the Wolleomo Historical Medical Musoum and Library and other grants to assist the history of medicine totalled $£ 120,000$. Commenting on the place of the Trust in support of research, the Trustees point out that hitherto the largest share in the grants made from the Trust's funds has boen for the provision of now buildings or the extension of those already available. They do not think under present conditions they should regard so extonsive an allocation for this purpose as a permanent feature of their policy, and they are watching the effect of the Robbins Report on the field of modical research. The position has been somewhat similar in regard to the provision of special items of rosearch equipment. The Trustess point out that far higher financial resources would be required to enable thom to accept responsibility for the permanent maintenance of research institutions as an established itom of policy. 'Thoir policy is largely based on the considera. tion of each problem on its merits and in relation to funds available from other sourees. They have also given thought to the special problem of support of research overseas, and consider that the need and opportunity for development of increasod knowledge of modical problems in the tropies are still vory great and the available funds limitod. Thoy are exploring ways in which thoy can promote medical research of high quality in and for the tropical aress with these general considerations in mind.

\section{Fluid Control}

AN informativo booklet entitled Pacemakers in Fluid Control has recently been publishod by the Hymatic Engineering Co. Ltd., a member of the Chloride Group (Pp. 32. Redditch: The Hymatic Ingineoring Company, Ltd.). This Company's activitics cover a wide range of interests in a highly specialized field which includes project studies in fluid control, and extend from propane reaction jet-control systems for satellites through miniature cooling systems producing liquid air, hydrogen, neon and helium, hot-air valves and control systems, fuol pressurization systoms including cornpstibility with oxotic fuel, to the full span of 'Hymatic' products. Fluid control is the art of manipulating the pressure and flow of both liquids and gases; these can rango from gases noar the temperature of the Sun creatod in plasma physies research down to 